\title{
民族的好要とその人格的要因*
}

\author{
熊本大学 \\ 葛谷隆 正**
}

\section{I 研究目的}

人はだれしも平和な社会・平和な世界を常に念願し, その実現のために絶えさる努力と協力を統けているとい つてよい。それにるかかわらず現実はその念願が容易に 実現されそうにもなく，かえつて人間相互間・国家相互 間の関係はますます相兛葛藤の度を加えつつあるかの観 を呈し, 心からの平和への念願す単に彼岸の夢に終わる のではないかとさえ舞われるのである。しかしやはり人 は永遠に人類の平和な世界の実現をめさして, 永久の努 力を緒けていくことと信ずる。

さて，わたくしはさる昭和29年 9 月，「諸民族に対す る好重の態度」に関する研究を試み，その結果を本誌第
3 巻に発表したが，あれから 5 年の歳月が経過した。そ の間, 内外の情勢は供然として刻々目まぐるしい変化を 続け，特に民族独立運動や原水爆・原子力の問題を中心 とするさまさまの世界平和建設のための国際的努力も東 西両陣営の考方方の相違対立による国際緊張を容易に楥 和しそうにない。このような情勢のさなかに生活する学 生は，はたしてどのような民族的好悪感を抱いているで あろらか，それは 5 年前のわのに比してはたしてどのよ 5な変化を示すであろらか，さらにこ5した民族的好德 は人格的構造とどのような関係をるつているであろう か,これらの問通にささやかな光をあてようと試みるこ

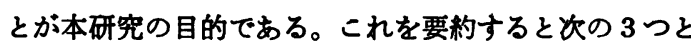
なる。

I 今日の大学生のもつ民族的好悪は 5 年前のそれと

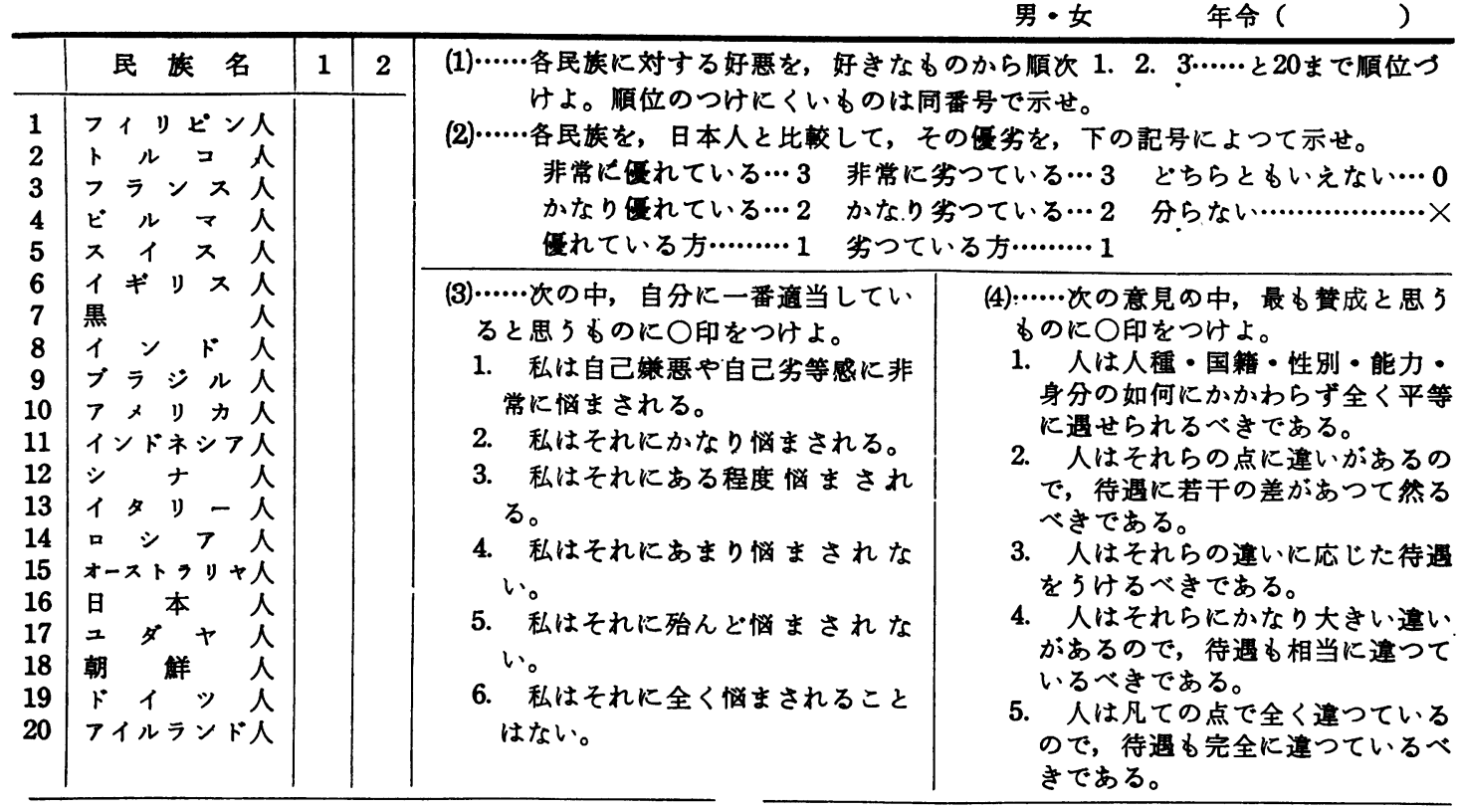

* Interracial preferences and their personality de-

** by Kuzutani, Takamasa (Kumamoto University) terminants. 
比較していかに変化しているか。

II 民族的好悪と民族に対する優劣観。

III 民族的好悪と人格的棈造との関係。

\section{II 研究手続き}

（1）被験者 熊本大学教育学部 1 ・ 2 年の学生 232 名で これを性別・年令別に示せば次のとおりである。調査 被 臨 者 数

\begin{tabular}{c|rrrr|r|r}
\hline 性別 & 18 才 & 19 & 20 & 21 & 計 & 平均年令 \\
\hline 男 & 55 & 43 & 5 & 3 & 106 & 18.58 \\
女 & 59 & 54 & 13 & 0 & 126 & 18.64 \\
\hline 言 & 114 & 97 & 18 & 3 & 232 & 18.61
\end{tabular}

は昭和34年 7 月初旬である。

（2）方法 別表のよ5な質問紙を配布し，集団的に行な つた。所要時間は䄪30分。あまりむつかしく考えない で頭の中に浮んできたありのままを卒直に書くように と特に念をおした。

\section{III 結果亡考察}

I 大学生の民族的好亜ならびに以前の研究結果との 比放

（1）各民族に対する好悪順位の分布状况

各民族に対する好悪順位の分布状況を\%（各順位こと に $\frac{100 \mathrm{f}}{\mathrm{N}}$ を算出) で示すと Table 1 のようになる。

Table 1 各民族に対する好悪順位の分布状况

\begin{tabular}{|c|c|c|c|c|c|c|c|c|c|c|c|c|c|c|c|c|c|c|c|c|}
\hline 族 & 1 & 2 & 3 & 4 & 5 & 6 & 7 & 8 & 9 & 10 & 11 & 12 & 13 & 14 & 15 & 16 & 17 & 18 & 19 & 20 \\
\hline フィリピン人 & & & & & & & & & & 0.1 & 7. 4 & 9.2 & & & & & & .7 & & \\
\hline トル $ン$ 人 & & & & & & & & & & & 6. 1 & & & & & 9.7 & .5 & 3.2 & 3. 2 & 0.9 \\
\hline フランス人 & & & & & & & 4. 1 & & .6 & 2.7 & 3. 6 & 1. & & & 1.8 & 0.5 & 9 & 0.5 & 0.5 & 0.9 \\
\hline ヒ ル マ & & 0 & 0 & & & & & & 6.4 & 9.7 & 6.4 & & ? & 2 & 10.1 & 8. 3 & 9.7 & 4. 1 & 3. 2 & 0.5 \\
\hline 人 & & 18 & 13 & & 10. & & 7. 2 & & 8 & & 2.3 & 1.8 & 2. 3 & 0.0 & 0.0 & 0.5 & .9 & 0.5 & 0.0 & 0.0 \\
\hline イギリス人 & & & & & & & 4. 9 & 4. & 0.0 & & 1.8 & 2. 2 & 0.9 & 0.5 & 1.3 & 1.8 & & 0.9 & 1. 3 & 0. \\
\hline 黒 & 0.9 & & 0. & & 0.9 & 2 & 3. 2 & & 4. 5 & 3. 6 & 4.5 & 6.4 & & 9.1 & 6.8 & 8. 2 & & 4 & 6.8 & 6.8 \\
\hline インド & & & 2.8 & & 7.4 & 6.5 & 8. 3 & 6.0 & 8. 3 & 6. 9 & 8. 8 & 3. 7 & 6. & 10.6 & 7.4 & 4. 1 & 3. 7 & 1.8 & 1.8 & 0.0 \\
\hline ブラジル & & & & & & 4. 5 & 7. 2 & & 10.0 & 6.8 & 8 & 10.9 & & 10.0 & 5.0 & 3. 6 & 5.4 & 1.8 & 1.8 & 0.0 \\
\hline フメリカ人 & 1.4 & & & & & & & & & 3. 2 & 1 & 3. 2 & & 3. 2 & 1.4 & 2.3 & 2 & 3. 6 & 1. 4 & 3. 2 \\
\hline インドネシフ人 & 0.0 & 0.0 & & & 0.9 & 2. 3 & 1. 8 & 0.9 & 2.8 & & 5. 1 & 8. 8 & $?$ & & 12. & 14. 3 & 9.2 & 4. 1 & 2.8 & 0.5 \\
\hline シ ナ & 00 & 1. 4 & 0.9 & 3. 2 & 1. 4 & 1. 4 & 1.8 & 1.8 & 2. 3 & 3.2 & 4.5 & 2.3 & 3. 6 & 4.5 & 8.6 & 4.5 & & & 20.9 & 12.7 \\
\hline イタリ - 人 & & 6.8 & 6. 3 & 9. 1 & & 13. 1 & 9 & 4. 0 & 2. 7 & 6.3 & 8. 6 & 2.7 & 4. 1 & 4. 1 & 1.4 & 0.0 & & 0. & 0.5 & 0.0 \\
\hline ロ シ $フ$ & 0.5 & & & 1. 4 & 1.8 & 3. 7 & 5. 5 & 4. 1 & 6.9 & 3. 2 & 6. 4 & 3. 2 & 2.8 & 4. 1 & 5.1 & 5.5 & & 12. & 12.4 & 12.0 \\
\hline オーストラリヤ人 & 0.0 & & & & & 3. 7 & 7. 3 & & 6.8 & 7. 8 & & 0.0 & 6.4 & 7. 3 & 5.9 & 5.5 & & 1.8 & 5.9 & 2. 3 \\
\hline 日本 人 & 47. 1 & U & 8. & 8. & 7. 1 & 4. 0 & 1.8 & & & 0.9 & & 0.9 & 0.0 & 0.5 & 0.9 & 0.9 & 05 & 0.5 & 1.8 & 0.9 \\
\hline$=$ ダ $ヤ$ 人 & 0. & & 0.9 & & 1. 4 & 1.8 & 0.9 & 2.8 & 1.8 & 5.5 & & & 10. 6 & & 5.5 & & & & 11. 1 & 5.5 \\
\hline 鮮 & 0.0 & & 0.0 & 0.0 & 0.9 & 0.0 & 0.9 & 0.0 & 0.5 & 0.9 & 0.9 & 3. 6 & 2.3 & & 2. 3 & 5. 0 & & & & 51. \\
\hline イッ人 & & & & & & & 6. 8 & & & 2.7 & & & & .4 & 1. 4 & .5 & & 0.0 & 0.5 & 0.0 \\
\hline アイルランド人 & & & & & & & & & & 8.3 & & & & & 5. 1 & 4. 1 & & 0.9 & 0.9 & 0.5 \\
\hline
\end{tabular}

それを類型的にみれば，

1. 右傾斜型一日本人, ドイツ人，スイス人，イギリ ス人, フランス人, アメリカ人

2. 左傾とつ型一イタリー人

3. とつ型一アイルランド人, オーストラリヤ人, ブ ラジル人,インド人

4. 右側とつ型一フィリ゚ン人, ビルマ人, インドネ シヤ人,トルコ人

5. 左傾斜型一朝鮮人, シナ人, ニダヤ人, ロシア人 黒人
となつている。これらの結果をさらに後述する好意度順 位群と連関させ, 昭和29年のものと比較して表示すると

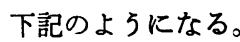

本研究には他の研究目的のためにあらたにアイルラン ド人とトルコ人が加えられているが，29年の結果に比し て好悪順位の分布状況はだいたい類似した傾向を示して いることがわかる。しかし次の諸点に㧊いていくらかの 変化を見ることができる。すなわち,

1. 以前第 3 群（左㑡とつ型）にあつたスイス人が第 2 群に入り, アメリカ人は同じ第 3 群に入るが, 分 


\begin{tabular}{|c|c|c|c|}
\hline & 分布型式 & 29 年 度 & 34 年 度 \\
\hline 1 & 右 傾 斜 型 & 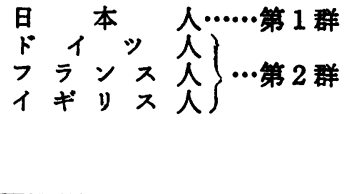 & 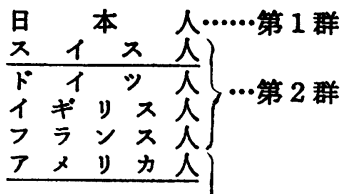 \\
\hline 2 & 左僋凸型 & 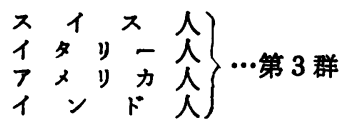 & イタリー人了…第 3 群 \\
\hline 3 & 波状水平型 & 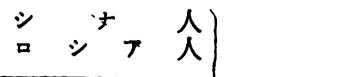 & な \\
\hline 4 & 凸 & ブラジル人 & 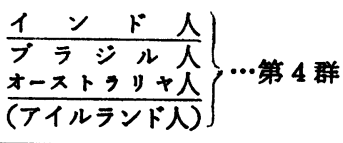 \\
\hline 5 & 右 㑡凸型 & 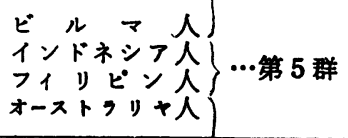 & 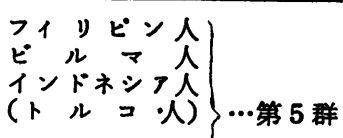 \\
\hline 6 & 左傾斜型 & $\begin{array}{l}\text { 黒 } \\
\text { 朝 } \\
\text { 鮮 }\end{array}$ & 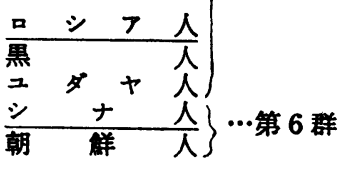 \\
\hline
\end{tabular}

布型式は右㑯斜型になつている

2. インド人は第 3 群から第 4 群 （とつ型）に変わつている。

3. 以前第 4 群 (波状水平型) $上$ あつたシナ人，ロシフ人は第 6 群（左傾斜型）に入つている。

4. さきに右㑡とつ型分布であつ たオーストラリヤ人は第 4 群の とつ型分布に変化している。

ぞして特に注目させられることは シナ人，ロシフ人によける分布状況 のいちじるしい変化である。これら の状況は次に考家する項目で一用明 白になるであろう。

（2）各民族に対する好意度および好 意度順位

各民族に対する好意度

$\left(\frac{1 f_{1}+2 f_{2} 3+f_{3}+\cdots \cdots \cdots \cdots \cdot+20 f_{20}}{N(\Sigma f)}\right)$ を算出すると Table 2 となる。本表 のS.D. 值をみて, アメリカ人, シ ナ人およびロシフ人においてそれが

Table 2 各民族に対する好意度とその順位

\begin{tabular}{|c|c|c|c|c|c|c|c|c|c|}
\hline \multirow[b]{2}{*}{ 民 族 } & \multicolumn{2}{|c|}{ 男 } & \multirow{2}{*}{ 順位 } & \multicolumn{2}{|c|}{ 女 } & \multirow{2}{*}{ 順位 } & \multicolumn{2}{|c|}{ 計 } & \multirow{2}{*}{ 順位 } \\
\hline & & S. D. & & & S. D. & & & S. D. & \\
\hline フィリピン人 & 12.35 & 3. 92 & 12 & 13. 42 & 3. 26 & 14 & 12. 93 & 3. 34 & 12 \\
\hline トル $ル 人$ & 12.86 & 3. 84 & 14 & 13. 39 & 2.96 & 13 & 13. 15 & 3. 39 & 14 \\
\hline フランス人 & 6. 63 & 4. 32 & 5 & 5. 18 & 2.80 & 5 & 5.86 & 3. 65 & 5 \\
\hline ビル $、 人$ & 12. 78 & 3. 36 & 13 & 13. 25 & 2.86 & 12 & 13. 03 & 3. 13 & 13 \\
\hline ス八ス人 & 4. 93 & 3. 44 & 3 & 4. 45 & 3. 22 & 2 & 4. 67 & 3. 34 & 2 \\
\hline 1 $\neq$ リ & 6.09 & 4. 52 & 4 & 4. 53 & 3. 62 & 3 & 5. 26 & 4. 19 & 4 \\
\hline 黒 人 & 13. 91 & 4. 52 & 18 & 13. 77 & 4. 18 & 16 & 13. 84 & 4. 32 & 17 \\
\hline インド人 & 10. 42 & 3. 94 & 9 & 10. 09 & 4. 16 & 8 & 10. 24 & 4. 06 & 8 \\
\hline ブラジル人 & 10. 15 & 4. 01 & 8 & 11.58 & 3. 57 & 10 & 10.86 & 4. 00 & 10 \\
\hline フメリカ人 & 8. 06 & 5. 28 & 7 & 7. 31 & 4. 84 & 6 & 7.65 & 5.07 & 7 \\
\hline インドネシア人 & 13. 52 & 3.58 & 17 & 13. 45 & $\overline{2.96}$ & 15 & 13. 48 & $\overline{3.30}$ & 15 \\
\hline シ ナ 人 & 14. 93 & 5. 48 & 19 & 15. 35 & 4. 29 & 19 & 15. 11 & 5.00 & 19 \\
\hline イタリー人 & 7.09 & $\overline{3.72}$ & 6 & 7.58 & $\overline{3: 60}$ & 7 & 7.36 & 3.65 & 6 \\
\hline 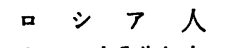 & 13. 39 & 5. 86 & 16 & 13. 82 & 5. 16 & 17 & 13. 62 & 5. 75 & 16 \\
\hline オーストラリヤ人 & 11. 30 & 4. 56 & 11 & 11. 69 & $\overline{3.50}$ & 11 & 11.51 & 4.03 & 11 \\
\hline 日 本 人 & 3. 70 & 4. 64 & 1 & 3. 20 & 3. 38 & 1 & 3. 43 & 4. 03 & 1 \\
\hline$=\not ゙ ヤ 人$ & 12. 97 & 4. 96 & 15 & 14. 78 & 3. 88 & 18 & 13. 96 & 4. 49 & 18 \\
\hline 朝 群 人 & 18. 18 & 2. 78 & 20 & 17. 99 & 2. 92 & 20 & 18.08 & 2.84 & 20 \\
\hline ドイッ人 & 4. 70 & 3. 98 & 2 & 4. 67 & 2.92 & 4 & 4. 68 & 3. 46 & 3 \\
\hline アイルランド人 & 10.81 & 3. 88 & 10 & 10.30 & 3.57 & 9 & 10. 53 & 3. 72 & 9 \\
\hline 平 & 10. 46 & 4. 23 & & 10. 49 & 3. 57 & & 10. 47 & 3. 94 & \\
\hline
\end{tabular}

男女間の好意度順位の列位相関 $\rho=0.973$. 
Table 329 年度結果と 34 年度結果との比較

\begin{tabular}{|c|c|c|c|c|c|c|}
\hline & \multicolumn{2}{|l|}{ 男 } & \multicolumn{2}{|l|}{ 女 } & \multicolumn{2}{|l|}{ 計 } \\
\hline & 好意度差|爪 & 順位差 & |好意度差| & 順位差 & |好意度差| & 順位差 \\
\hline 日 本 人 & -1.59 & 0 & -0.96 & 0 & -1.20 & 0 \\
\hline 朝 鮮 人 & -1.66 & 0 & -1.43 & 0 & -1.55 & 0 \\
\hline シ ナ 人 & -4.46 & -8 & -2.18 & -7 & -3.64 & -8 \\
\hline フィリピン人 & +2.04 & +3 & +0.18 & +1 & +1.17 & +3 \\
\hline ビル $>$ 人 & -1.34 & -3 & +0.17 & +1 & -0.85 & -1 \\
\hline インドネシア人 & +0.14 & -2 & +0.96 & +1 & +0.46 & 0 \\
\hline インド 人 & -2.15 & -2 & -1.41 & -1 & -1.82 & -1 \\
\hline オーストラリヤ人 & +3.85 & +5 & +2.92 & +6 & +3.44 & +5 \\
\hline イタリー人 & +1.01 & 0 & +0.14 & -1 & +0.60 & 0 \\
\hline フランス人 & -0.68 & -2 & -0.83 & -3 & -0.50 & -2 \\
\hline スイス人 & +1.74 & +2 & +1.86 & +3 & +1.94 & +3 \\
\hline ドィ人 & +0.63 & 0 & -0.08 & -1 & +0.38 & -1 \\
\hline イギリス人 & +0.49 & 0 & +0.23 & +1 & +0.66 & 0 \\
\hline 口 シ 7 人 & -1.01 & -2 & -0.51 & -4 & -1.00 & -2 \\
\hline フメリカ人 & +1.41 & +1 & +1.65 & +2 & +1.63 & +1 \\
\hline 黒 人 & +1.46 & 0 & +1.24 & +3 & +1.44 & +1 \\
\hline ブラシル人 & +1.38 & +3 & +1.22 & 0 & +1.07 & +1 \\
\hline 二ダヤ人 & +2.84 & +4 & -0.21 & -1 & +1.39 & +1 \\
\hline 男子の両众 & 三度の好意 & 度順位 & 利位相関 & $\rho=$ & 0.842 & \\
\hline 女子の & " & $"$ & & & $\begin{array}{l}0.856 \\
0.874\end{array}$ & \\
\hline
\end{tabular}

ことができよ5。Table 3から最も䫓著なる のをあげると, シナ人に対するいちじるしい 非好意的態度への推移と，それとは反対にオ ーストラリヤ人に対するはつきりした好意的 態度への変化である。男子におけるニダヤ人 に対する態度もいちじるしく好意的に变わつ ている。かかる変化はそれらの民族ないし国 民の当方に対する激しい拒否的ないし敵対的 態度が停止または改善されるとか，逆にかれ らの態度が好意的友好的であつたのが，きわ めて非好意的拒否的となつてきた場合に起こ ることが反省される。また他の民族に対する 認識の深さ，理解の深さによつてこちらの態 度が变化する。ユダヤ人に対する態度の変化 などはこれに基ついているすのと考えられ る。好意度の变化の状況をまとめてみると次 のよ5になる。

ここに一考を要する事実が現われている。 それは自国民に対する態度が非好意的な方向 に変化していることである。最近の国内情勢 は上下あげての勢力争い, 各種犯罪の横行, 交通禍の激化，ストライキの年中行事化，入 学試験・就職試験の激烈化等実際目をおお 5 べきものがあり，純粋と理想に燃える青年学
他に比していちじるしく大きいことに気つくのであるが この事実は前項であきらかにされたこれら諸民族に対す る学生の好意度に以前と異なつたものが生じているこ とを物語つているといつてよく，なお学生個人によつて 相当に好意度に变化のあることを示している。いま，29 年の研究と本研究との比較を各民族に対する好意度差お よび順位差によつて示せば Table 3のようになる（29年 度の研究は18民族であつたので,好意度 $\mathrm{P}_{2}=\frac{20 \mathrm{P}_{1}}{18}$ として 换算した）。

両年度における好意度順位列位相関係数は男子で 0.842, 女子で 0.856 ，全体では 0.874 と相関度は予想 外に高いので，学生の各民族に対する好意度は時間的経 過や社会的国際的事変の变化にもかかからず，かなり恒 常的な永続的傾向のあることが考えられる。この点は Guilford, J. P. (1) や Hartley, E. L. (2) 等の研究結 果と一致している。

しかし Seago, D. W. (3), Meenes, M. (4), Gilbert, G. M. (5) 等が太平洋戦争前からその後にかけての アメリカ人学生の日本人，ドイッ人に対する態度が好意 的なものから非好意的なものに推移した模様をあきらか にしているが，本研究においても同様の傾向を例示する

\begin{tabular}{|c|c|c|c|c|c|c|}
\hline $\begin{array}{l}\text { り好意的な } \\
\text { 方向へ変化し } \\
\text { このの }\end{array}$ & 順 & $\begin{array}{l}\text { より } \\
\text { 方向 } \\
\text { むの }\end{array}$ & へ变 & & 順 & $\begin{array}{l}\text { あまり変化して } \\
\text { いないいの }\end{array}$ \\
\hline 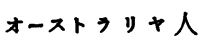 & 1 & シ & ナ & 人 & 1 & インドネシフ人 \\
\hline ス 1 人 & 2 & 1 & ソ & 人 & 2 & ビル $>$ 人 \\
\hline フメリカ人 & 3 & 朝 & 鮮 & 人 & 3 & イタリー人 \\
\hline 黒 人 & 4 & 日 & 本 & 人 & 4 & フランス人 \\
\hline $\begin{array}{l}\text { ュ゙ャ } \\
\text { フィリピン人 } \\
\text { ブラジル人 }\end{array}$ & $\left|\begin{array}{l}5 \\
6 \\
7\end{array}\right|$ & & シ 7 & & 5 & 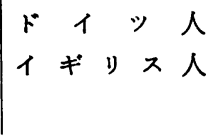 \\
\hline
\end{tabular}

徒にとつてはことに見苦しく污らわしい奖に映ずること であろう。「青年よ! 大望を抱け！」と叫ばれうる希 望と光明と誇りを持ち5る日本人に一日る早くなりたい ஆのである。

\section{II 大学生の民族的好度と民族に対する偍少视との 时你}

（1）各民族に対する優劣度の分布状况

各民族に対する優劣度の分布状況を\%（各段階毎に $\frac{100 f}{N}$ を算出）で示すと Table 4 となる。同表の右方欄に はさらに各民族に対する優劣点が示してあるが，これは + 3 の段階に7点を与え, +2には 6 点, + 1 には 5 点, ... 
Table 4 各民族に対する優劣度分布状況（\%)

\begin{tabular}{|c|c|c|c|c|c|c|c|c|c|c|c|}
\hline & +3 & +2 & +1 & 0 & -1 & -2 & -3 & 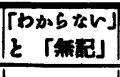 & 但劣点 & S. D. & 順位 \\
\hline フィリピン人 & $\overline{-}$ & - & $\begin{array}{l}4.7 \\
4.0\end{array}$ & $\begin{array}{r}17.8 \\
6.5\end{array}$ & $\begin{array}{l}35.5 \\
42.3\end{array}$ & $\begin{array}{l}27.1 \\
16.3\end{array}$ & $\begin{array}{l}5.6 \\
1.6\end{array}$ & $\begin{array}{r}9.3 \\
29.3\end{array}$ & 2.90 & 1.53 & 15 \\
\hline$r M=人$ & $=$ & $=$ & $\begin{array}{l}0.9 \\
1.6\end{array}$ & $\begin{array}{l}17.8 \\
10.6\end{array}$ & $\begin{array}{l}28.0 \\
25.2\end{array}$ & $\begin{array}{l}28.0 \\
15.4\end{array}$ & $\begin{array}{l}1.9 \\
1.6\end{array}$ & $\begin{array}{l}23.4 \\
45.5\end{array}$ & 2.87 & 1.26 & 16 \\
\hline フランス人 & $\begin{array}{l}8.4 \\
9.8\end{array}$ & $\begin{array}{l}12.1 \\
27.6\end{array}$ & $\begin{array}{l}23.4 \\
35.0\end{array}$ & $\begin{array}{l}44.9 \\
21.9\end{array}$ & $\begin{array}{l}5.6 \\
2.4\end{array}$ & 1.9 & - & $\begin{array}{l}3.7 \\
\text { 3. } 3\end{array}$ & 4.96 & 1.08 & 5 \\
\hline ビルマ人 & - & $0 . \overline{8}$ & $\begin{array}{l}1.9 \\
1.6\end{array}$ & $\begin{array}{l}11.2 \\
10.6\end{array}$ & $\begin{array}{l}26.3 \\
33.3\end{array}$ & $\begin{array}{l}35.5 \\
23.6\end{array}$ & $\begin{array}{r}12.1 \\
4.9\end{array}$ & $\begin{array}{l}13.0 \\
25.2\end{array}$ & 2.63 & 0.95 & 17 \\
\hline ス $12 人$ & $\begin{array}{r}10.4 \\
7.3\end{array}$ & $\begin{array}{l}20.8 \\
23.6\end{array}$ & $\begin{array}{l}19.8 \\
23.6\end{array}$ & $\begin{array}{l}35.8 \\
29.3\end{array}$ & $\begin{array}{l}2.8 \\
6.5 .\end{array}$ & $=$ & $=$ & $\begin{array}{r}10.4 \\
9.8\end{array}$ & 4. 98 & 1.00 & 4 \\
\hline イギリス人 & $\begin{array}{l}17.0 \\
21.9\end{array}$ & $\begin{array}{l}23.6 \\
39.8\end{array}$ & $\begin{array}{l}30.2 \\
28.5\end{array}$ & $\begin{array}{r}23.6 \\
8.1\end{array}$ & $\begin{array}{l}0.9 \\
0.8\end{array}$ & 1.9 & 0.9 & $\begin{array}{l}1.9 \\
0.8\end{array}$ & 5.51 & 1.04 & 2 \\
\hline イント人 & $0 . \overline{8}$ & $\begin{array}{l}2.9 \\
0.8\end{array}$ & $\begin{array}{l}7.6 \\
5.7\end{array}$ & $\begin{array}{l}11.4 \\
19.5\end{array}$ & $\begin{array}{l}31.4 \\
39.8\end{array}$ & $\begin{array}{l}28.6 \\
21.9\end{array}$ & $\begin{array}{r}10.5 \\
1.6\end{array}$ & $\begin{array}{l}7.6 \\
9.8\end{array}$ & 3. 00 & 1.11 & 14 \\
\hline ブラジル & 1.0 & $\begin{array}{l}0.8 \\
2.9\end{array}$ & $\begin{array}{l}4.0 \\
\text { 3. } 8\end{array}$ & $\begin{array}{l}22.8 \\
16.2\end{array}$ & $\begin{array}{l}26.8 \\
46.7\end{array}$ & $\begin{array}{l}\text { 17. } 1 \\
17.1\end{array}$ & $\begin{array}{l}4.0 \\
2.9\end{array}$ & $\begin{array}{r}24.4 \\
9.5\end{array}$ & 3. 13 & 1.03 & 12 \\
\hline フメリカ人 & $\begin{array}{l}20.0 \\
15.4\end{array}$ & $\begin{array}{l}25.7 \\
35.0\end{array}$ & $\begin{array}{l}22.9 \\
21.0\end{array}$ & $\begin{array}{l}\text { 18. } 1 \\
17.1\end{array}$ & $\begin{array}{l}5.7 \\
6.5\end{array}$ & $\begin{array}{l}1.9 \\
0.8\end{array}$ & $\begin{array}{l}3.8 \\
0.8\end{array}$ & $\begin{array}{l}1.9 \\
3.2\end{array}$ & 5. 19 & 1. 37 & 3 \\
\hline インドネシフ人 & 二 & 二 & $=$ & $\begin{array}{r}5.7 \\
11.4\end{array}$ & $\begin{array}{l}36.3 \\
29.3\end{array}$ & $\begin{array}{l}34.3 \\
22.8\end{array}$ & $\begin{array}{r}13.3 \\
5.7\end{array}$ & $\begin{array}{l}10.5 \\
30.9\end{array}$ & 2.58 & 0.84 & 18 \\
\hline シ $ナ 人$ & 1.0 & $\begin{array}{l}1.9 \\
1.0\end{array}$ & $\begin{array}{l}7.6 \\
4.9\end{array}$ & $\begin{array}{l}18.1 \\
21.9\end{array}$ & $\begin{array}{l}30.5 \\
42.3\end{array}$ & $\begin{array}{l}24.8 \\
13.0\end{array}$ & $\begin{array}{r}13.3 \\
7.3\end{array}$ & $\begin{array}{l}2.9 \\
9.8\end{array}$ & 3.00 & 0.98 & 13 \\
\hline $1 \& y-1$ & 1.9 & $\begin{array}{l}4.8 \\
7.3\end{array}$ & $\begin{array}{l}12.4 \\
13.0\end{array}$ & $\begin{array}{l}47.6 \\
47.9\end{array}$ & $\begin{array}{l}18.1 \\
10.6\end{array}$ & $\begin{array}{l}3.8 \\
1.0\end{array}$ & $\frac{1.0}{-}$ & $\begin{array}{l}10.5 \\
20.3\end{array}$ & 4.09 & 0.92 & 7 \\
\hline 口: & $\begin{array}{r}10.5 \\
8.1\end{array}$ & $\begin{array}{l}16.2 \\
29.3\end{array}$ & $\begin{array}{l}18.1 \\
17.1\end{array}$ & $\begin{array}{l}21.9 \\
20.3\end{array}$ & $\begin{array}{l}13.3 \\
10.6\end{array}$ & $\begin{array}{l}2.9 \\
4.9\end{array}$ & $\begin{array}{l}4.8 \\
1.6\end{array}$ & $\begin{array}{r}12.4 \\
8.1\end{array}$ & 4. 70 & 1.50 & 6 \\
\hline オーストラリフ人 & 1. 0 & $\begin{array}{l}2.9 \\
0.8\end{array}$ & $\begin{array}{r}9.5 \\
10.6\end{array}$ & $\begin{array}{l}32.4 \\
24.4\end{array}$ & $\begin{array}{l}26.7 \\
19.5\end{array}$ & $\begin{array}{l}4.8 \\
4.0\end{array}$ & $\begin{array}{l}1.0 \\
0.8\end{array}$ & $\begin{array}{l}21.9 \\
39.8\end{array}$ & 3. 72 & 0.96 & 10 \\
\hline 日本人 & - & - & - & - & - & - & - & - & 4. 00 & - & 8 \\
\hline$=\not ゙+人$ & $\begin{array}{l}7.6 \\
2.4\end{array}$ & $\begin{array}{l}3.8 \\
2.4\end{array}$ & $\begin{array}{l}8.6 \\
6.5\end{array}$ & $\begin{array}{r}16.2 \\
8.9\end{array}$ & $\begin{array}{l}17.1 \\
28.5\end{array}$ & $\begin{array}{l}14.3 \\
11.4\end{array}$ & $\begin{array}{l}4.8 \\
9.8\end{array}$ & $\begin{array}{l}27.6 \\
30.1\end{array}$ & 3. 40 & 1.58 & 11 \\
\hline 朝 鮮人 & I & Z & 2.9 & $\begin{array}{l}6.7 \\
4.0\end{array}$ & $\begin{array}{l}25.7 \\
37.4\end{array}$ & $\begin{array}{l}25.7 \\
29.3\end{array}$ & $\begin{array}{l}33.3 \\
21.9\end{array}$ & $\begin{array}{l}5.7 \\
7.3\end{array}$ & 2.21 & 0.90 & 19 \\
\hline トイッ人 & $\begin{array}{l}35.2 \\
33.3\end{array}$ & $\begin{array}{l}28.6 \\
34.1\end{array}$ & $\begin{array}{l}22.9 \\
20.3\end{array}$ & $\begin{array}{l}11.4 \\
10.6\end{array}$ & 1.0 & 二 & 二 & $\begin{array}{l}1.0 \\
1.6\end{array}$ & 5.92 & 1.02 & 1 \\
\hline フイルランド人 & $\begin{array}{l}1.0 \\
0.8\end{array}$ & 1.0 & $\begin{array}{l}7.6 \\
9.8\end{array}$ & $\begin{array}{r}24.8 \\
.13 .0\end{array}$ & $\begin{array}{l}\text { 16. } 2 \\
13.0\end{array}$ & 4. 8 & 1.9 & $\begin{array}{l}42.8 \\
63.4\end{array}$ & 3. 80 & 1.01 & 9 \\
\hline 人 & 1.9 & $1 . \overline{6}$ & $3 . \overline{2}$ & $\begin{array}{l}6.7 \\
4.0\end{array}$ & $\begin{array}{l}17.1 \\
18.7\end{array}$ & $\begin{array}{l}21.9 \\
26.0\end{array}$ & $\begin{array}{l}45.7 \\
\text { 33. } 3\end{array}$ & $\begin{array}{r}6.7 \\
13.0\end{array}$ & 2.03 & 1.06 & 20 \\
\hline 平均 & & & & & & & & & $3.73^{\circ}$ & 1.06 & - \\
\hline
\end{tabular}

上段……男子，下段……女子

一 3 段階には 1 点を与えて, $\frac{{ }^{7} f_{+3}+{ }^{6} f_{+2}+{ }^{5} f_{+1} \cdots \cdots \cdot+{ }^{1} f_{-3}}{\Sigma f}$ の値を計算したもので，点数の多いはどよりすぐれてい ることを示し，また 4 点以上ならば日本人よりすぐれて いる，4 点以下ならば日本人より劣つていることを示し ている。なおこの優劣点， S. D. およびその順位の欄は すべて男女合計したすのについてである。後に掍げる Table 5 によつて各民族に対する優劣点に関する男女間 の状況をみると，警くほどに類似をた順位を示していて，
その列位相関係数は実に 0.973 の高さに達している。 そこで Table 4 によつて各民族のるつ優劣点を全体的 に考察してみよう。

第1に，日本人よりすぐれていると評価されている民 族は 7 民族であつて，優劣点の最高のものから並べてみ ると, ドイッ人,イギリス人, アメリカ人, スイス人, フランス人，ロシフ人，イタリー人となり，ほとんとが 非常に好意をもたれている民族である。ただロシフ人の 
みはその好意度において16位にありながら，優劣度では 第 6 位を占めている。この事実から好意度と優劣度とが 完金に一致するとは言いがたいといらことがわかる。つ まり，民族的態度における認識的側面と感情的側面とは だいたいにおいてよく一致するが，といつても常に必ら ずしもそうではないといえよう。この点に関しては次項 でいま少し詳しく検討することとする。

第 2 に，日本人より劣つていると評価されているすの は他の12民族であつて，最も劣つているとされているも のから列挙してみると, 黒人, 朝鮮人, インドネシア人 ビルマ人, トルコ人, フィリピン人, インド人, シナ人 ブラジル人，ニダヤ人，オーストラリヤ人，アイルラン ド人といら順序になる。しかし，オーストラリヤ人，ト ルコ人，アイルランド人に関しては「かからない」反応 や無記反応が $30 \%$ 以上もあり，特にアイルランド人では 53. 9\%にも達しているので，ここに示された評価点もこ の事実を考慮して解釈されねばならないだ ろ5。

またユダヤ人，フィリピン人，ロシフ人 などに対しては分布がかなり広く分散して おり；評価の個人差が大きいということも 考慮にいれて打く必要がある。

（2）民族的好意度と優劣度との関係

この問題については前項で一言触れてお いたのであるが，まず調査の結果を Table 5によつてよく観察してみよう。

全体的に両者間のずれの大きいるのを調 べてみると, Table 5 から次のような結果 が得られる。

次に男女における両者の一致度をみると 男子では列位相関係数が 0.768 ，女子では 0.754 であり，全体では 0.760 であるから 一致度はかなり高いといってよい。しかも 男女間における優劣度の列位相関係数は実 に0.973 といらいちじるしい一致の傾向が ある。

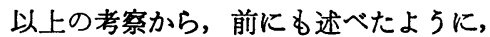
民族的優劣観と民族的好悪感とは相関度は かなり高いが，両者間のずれの大きいもの もあるといらことがあきらかとなつた。 Katz，D. と Braly，K. W. (6) とはすで に25年前に，好意度では第 4 位にあつたイ タリー人が第 6 位にあつた日本人よりも民 族的ステレオタイプにおいて（日本人はこ の点で第 4 位) より非好意的なるのであつ

\begin{tabular}{|c|c|c|c|c|}
\hline $\begin{array}{l}\text { 優劣度が好意度 } \\
\text { よりも高いもの }\end{array}$ & 順 & $\begin{array}{l}\text { 好意度が優劣度 } \\
\text { よりも高いもの }\end{array}$ & 順 & $\begin{array}{l}\text { 画者間のずれの } \\
\text { 少いもの }\end{array}$ \\
\hline 口 $シ 7 人$ & 1 & 日 本 人 & 1 & フランス人 \\
\hline$=\not ゙+人$ & 2 & イ.ンド人 & 2 & イタ \\
\hline$ナ$ & 3 & ビル $、$ 人 & 3 & オーストラリヤ人 \\
\hline 丁メリカ人 & 4 & フィリピン人 & 5 & フイルランド人 \\
\hline イギリ & 5.5 & & 5 & 鮮 \\
\hline ド イ ッ & 5.5 & $\begin{array}{l}\text { インドネシア人 } \\
\text { ブラシ ル } \\
\text { ル } \\
\text { ス } \\
\text { イ } \\
\text { ス }\end{array}$ & $\begin{array}{l}5 \\
8 \\
8 \\
8\end{array}$ & \\
\hline
\end{tabular}

たことを指摘し，民族的好悪感と民族的ステレオタイプ とが必らずしも一致しないことを示唆している。本研究 ではこの点が一層明確に例証されていると考える。

なお筆者がこの調査整理中激しい衝撃を受けた事実を 報告しておかなければならない。それは女性の一被験者

Table 5 民族的好意度と優劣度との関係

\begin{tabular}{|c|c|c|c|c|c|c|c|c|c|}
\hline \multirow[b]{2}{*}{ 民 嗾 } & \multicolumn{3}{|c|}{ 男 } & \multicolumn{3}{|c|}{ 女 } & \multicolumn{3}{|c|}{ 計 } \\
\hline & $\begin{array}{l}\text { 優 } \\
\text { 劣 } \\
\text { 点 }\end{array}$ & \begin{tabular}{|l|}
$\mid$ 優順 \\
劣 \\
度位
\end{tabular} & $\begin{array}{l}\text { 学順 } \\
\text { 复位 }\end{array}$ & $\begin{array}{l}\text { 優 } \\
\text { 劣 } \\
\text { 点 }\end{array}$ & \begin{tabular}{|l|}
$\mid$ 優順 \\
度位 \\
\end{tabular} & \begin{tabular}{|l|} 
好順 \\
意 \\
度位
\end{tabular} & $\mid$\begin{tabular}{|l}
$\mid$ 優順 \\
\end{tabular} & \begin{tabular}{|l|} 
好順 \\
意 \\
度位 \\
\end{tabular} & 差 \\
\hline フィリピン人 & 2.62 & 16 & 12 & 2.93 & 15 & 14 & 15 & 12 & +3 \\
\hline トル コ人 & 2.84 & 15 & 14 & 2. 91 & 16 & 13 & 16 & 14 & +2 \\
\hline フランス人 & 4. 66 & 5 & 5 & 5. 21 & 4 & 5 & 5 & 5 & 0 \\
\hline ビル $マ$ 人 & 2. 48 & 17 & 13 & 2. 77 & 17 & 12 & 17 & 13 & +4 \\
\hline スイス人 & 5.00 & 4 & 3 & 4. 96 & 5 & 2 & 4 & 2 & +2 \\
\hline イギリス人 & 5.23 & 2 & 4 & 5. 75 & 3 & 3 & 2 & 4 & -2 \\
\hline 黒 人 & 1.94 & 20 & 18 & 2.11 & 20 & 16 & 20 & 17 & +3 \\
\hline インド人 & 2.85 & 14 & 9 & 3.13 & 11 & 8 & 14 & 8 & +6 \\
\hline ブラジル人 & 3.15 & 12 & 8 & 3. 11 & 13 & 10 & 12 & 10 & +2 \\
\hline アメリカ人 & 5. 16 & 3 & 7 & 5. 80 & 2 & 6 & 3 & 7 & -4 \\
\hline インドネシフ人 & 2.38 & 18 & 17 & 2.67 & 18 & 15 & 18 & 15 & +3 \\
\hline シ ナ 人 & 2.91 & 13 & 19 & 3. 07 & 14 & 19 & 13 & 19 & -6 \\
\hline イタリー人 & 3.99 & 8 & 6 & 3. 83 & 9 & 7 & 7 & 6 & +1 \\
\hline 口 シ ア 人 & 4. 55 & 6 & 16 & 4. 81 & 6 & 17 & 6 & 16 & -10 \\
\hline オーストラリヤ人 & 3. 73 & 9 & 11 & 3. 70 & 10 & 11 & 10 & 11 & -1 \\
\hline 日本 人 & 4. 00 & 7 & 1 & 4. 00 & 7 & 1 & 8 & 1 & +7 \\
\hline$=$ ダ & 3. 71 & 10 & 15 & 3. 12 & 12 & 18 & 11 & 18 & -7 \\
\hline 朝＼cjkstart鮮 & 2.15 & 19 & 20 & 2.25 & 19 & .20 & 19 & 20 & -1 \\
\hline ドイッ人 & 5. 92 & 1 & 2 & 5.92 & 1 & 4 & 1 & 3 & -2 \\
\hline フイルランド人 & 3. 67 & 11 & 10 & 3. 98 & 8 & 9 & 9 & 9 & 0 \\
\hline 平 & 3.65 & a. & b & 3.81 & c & d & e & f & \\
\hline$a b$ 間の列位 & & $\rho=0$ & 76 & & & & & & \\
\hline cd間 " & & $\rho=0$ & 75 & & & & & & \\
\hline ef 間 & & $\rho=0$ & 760 & & & & & & \\
\hline ac間 & & $\rho=0$ & 97 & & & & & & \\
\hline
\end{tabular}


（18才）が䆩䦓の第 1・第 2 項に対して無庶答の5え，

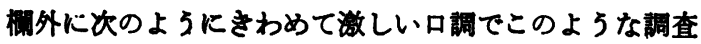
に対する異議を訴えていたということである。

「外国人についての知識はほとんどといつていいくらい： ないわれわれになせこのようなことがわかるでしょう。 優劣だなどと、いつたい何を基準としてのことなのか ?」と。こ5した異議については奇しくも Gilbert, G. M. (7)が大学生について行なつた民族的ステレオタイブ の調查の際にも多数の学生から発せられたことを報告し ている。

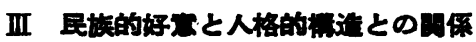

この問題については Adorno, T. W. ら (8) があの 「The Authoritarian Personality」を公けにして以来さ かんに研究されるよ5になつた。そして人種中心主義と 権威主義とが密接に関連していることをあきらかにして きている。しかし最近，人種中心主義とは反対方向の外 国人に対する好意的態度を中心とした研究に関心の中心 が向けられてきた。たとえば Perlmutter，H. V. (9) は外国人や外国交化に強い好意的態度をるつているるの はそうでないすのよりす有意的に権威主義的であること をあきらかにしており，このよらな外国びいきの強いる のは根本的には権威主義的な傾向の強いものと同一の人 格的力学構造をるつていると考えた。また Brodbeck,

A. J. (10) は外国人や外国文化に強い好意をるつものは その反対のものよりす自己嫌悪感がより強い傾向のある こと，および権威主義的傾向の強いものも彁いものより より自己嫌德が強いことを報告している。そしてこうし た自己嫌悪感は，自信感とか自尊心感が人生初期におけ る健康的な親子関係から生ずるのに反し，不幸な親子関 保から起こると考える。さらに直接的な親の否定的拒否 的態度によつて生じた自己咩悪感の補傊機制として内集 団との強い同一化現象が起こり，これが民族的態度とし ては人種中心主義的人間を形成する。これに反し, 同一 化すべきモデルとして親が不適当である場合には，自己 嫌悪感を外集団との同一化によつて除こうとし，これが 外国びいきの態度として現われると考えるのである。こ らしてかれは異なつた親子間の葛藤から生ずるとはいえ 同じ自己嫌悪感を抱くものが一方では人種中心主義的人 格となり，他方それとは正反対の外国びいきの人格とな ることを論じている。

筆者は Brodbeck, A. J. の所論に刺激されて, 偏見 的人格と外国びいきの人格と自己嫌悪感との 3 者の関係 を明かにしようと意図した。

この場合, 外国びいきの人格 (Xenophilic Personality 略して XP)，とは䆩問籷第 1 項の調查において日本人に
対し第 7 位以下に順位つけたるのとし，上・中・下.3 群 に分類する。偏見的人格(Prejudiced Personality 略して PP） とは質問妹第 4 項の 2 以下沉反応したるのとし， 偏見点を算出するために，5点尺度法を用い，1に1点 2 に 2 点……とい 5 ぐあいに採点した。自己咩德感につ いては質問紙第 3 項を 6 点尺度として，1に6 点，2に 5 点……とい5ぐあいに採点して自己嫌德点を算出し た。

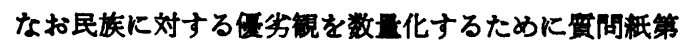
2 項を 7 点尺度とし， + 3 は 7 点, +2 は 6 点, ......, ー 1 は1点として計算して優贫点を求めた。また被監者 の中に無記反応が約15\%近くあつたのでこれらを除い て結果を考察することにした。

（1）XP. は侉劣点・自己嫌㩊点・偏見点において，どの ような傾向を示したか。

この間通に関して調查結果を整理すると Table 6 のよ ろになる。外国びいきの傾向のいちしるしいすの，中程

Table 6 男子学生

\begin{tabular}{|c|c|c|c|c|c|c|c|}
\hline & 数 & 儤劣点 & $\mathrm{SD}^{2}$ & 息悪点 & $\mathrm{SD}^{2}$ & 儒見点 & $\mathrm{SD}^{2}$ \\
\hline 上 & 19 & 3. 86 & 3. 944 & 4. 68 & 1.547 & 1. 16 & 0.448 \\
\hline 中 & 19 & 3. 78 & 4. 021 & 4. 42 & 1.298 & 1.68 & 0.532 \\
\hline 下 & $\begin{array}{c}51 \\
(89)\end{array}$ & 3. 47 & 3. 641 & 3. 94 & 3. 373 & 1. 49 & 0. 287 \\
\hline & & $\begin{array}{l}3.61 \\
0.01\end{array}$ & 4. 085 & $\begin{array}{l}4.20 \\
0.01\end{array}$ & 1.600 & $\begin{array}{l}1.46 \\
0.01\end{array}$ & 0.361 \\
\hline
\end{tabular}

.女子学 生

\begin{tabular}{l|c|c|c||c|c||c|c}
\hline 上 & 16 & 4.03 & 4.744 & 4.88 & 0.494 & 1.38 & 0.359 \\
中 & 43 & 3.91 & 3.626 & 4.51 & 0.856 & 1.35 & 0.226 \\
下 & 53 & 3.85 & 2.111 & 4.66 & 1.168 & 1.43 & 0.661 \\
& $(112)$ & & & & & & \\
平 & 均 & 3.89 & 3.141 & 4.63 & 0.964 & 1.39 & 0.450 \\
\multicolumn{2}{l|}{ 有意水濩 } & 0.01 & & 0.01 & & $0.20>\mathrm{p}>0.10$
\end{tabular}

男女計

\begin{tabular}{l|c|c|c||c|c||c|c}
\hline 上 & 35 & .3 .94 & 4.616 & 4.77 & 0.867 & 1.26 & 0.392 \\
中 & 62 & 3.87 & 3.779 & 4.48 & 0.992 & 1.45 & 0.344 \\
下 & 104 & 3.66 & 3.452 & 4.31 & 1.558 & 1.46 & 0.499 \\
& $(201)$ & & & & & & \\
平 & 均 & 3.77 & & 4.41 & & 1.42 & \\
\multicolumn{2}{l|}{ 有意水準 } & 0.01 & & 0.01 & & 0.01 &
\end{tabular}

度のもの，低いもの（順位つけで第 1 位としたすの）に 分類して各成績における上下両群の差を t-test してみる そ，女子学生における偏見点の場合を除いてすべて0.01 水準以上において有意差がある。

これによつてみると，外国びいきの傾向の強いすのほ 
どそれの弱いものよりも優劣点・自己嫌悪点において より高い成績をとり，嫌悪点においてはより低い成績を とる傾向のむることがわかる。ただ女子学生の場合，偏 見点については前述の傾向がはつきり有意的には出てい ない。

なお，優劣点・自己嫌悪点および偏見点のそれぞれに ついて男女の成績の有意差を $\mathrm{t}$-test すると，いずれの場 合にも0.01水準以上に扎いて有意差があり，女子は優劣 点・自己嫌悪点において男子ょり高い値をとり，偏見点 においてより低い成績をとる傾向を見出すことができ る。

次に前にも考察したよ $5 に ＼mathrm{~ 民 族 的 好 悪 感 と 民 族 的 優 ~}$ 劣観とは必らずしも一致しないが，それでも本調査では 0.750 以上の相関があつたのであるから，今の結果を優 劣点の分布から被験者を分類して比較してみたら，おそ らく同様の結果が得られるのではないかといらことが予 想されよう。この目的でまとめたるのが Table 7である。

Table 7 男子学生

\begin{tabular}{|c|c|c|c|c|c|c|}
\hline & 数 & 優劣点 & 息已 & $\mathrm{SD}^{2}$ & 偏見点 & $\mathrm{SD}^{2}$ \\
\hline 上 & 23 & 4. 39 & 4. 61 & 1. 401 & 1. 22 & 0.170 \\
\hline 中 & 31 & 3. 75 & 4. 65 & & 1. 48 & \\
\hline 下 & $\begin{array}{c}35 \\
(89)\end{array}$ & 2. 97 & 3. 23 & 1. 622 & 1. 60 & 0.526 \\
\hline 平 & 均 & 3. 61 & 4. 20 & 1. 674 & 1. 46 & 0.361 \\
\hline \multicolumn{2}{|c|}{ 有意水淮 } & & \multicolumn{2}{|c|}{0.01} & \multicolumn{2}{|c|}{0.01} \\
\hline
\end{tabular}

女子学 生

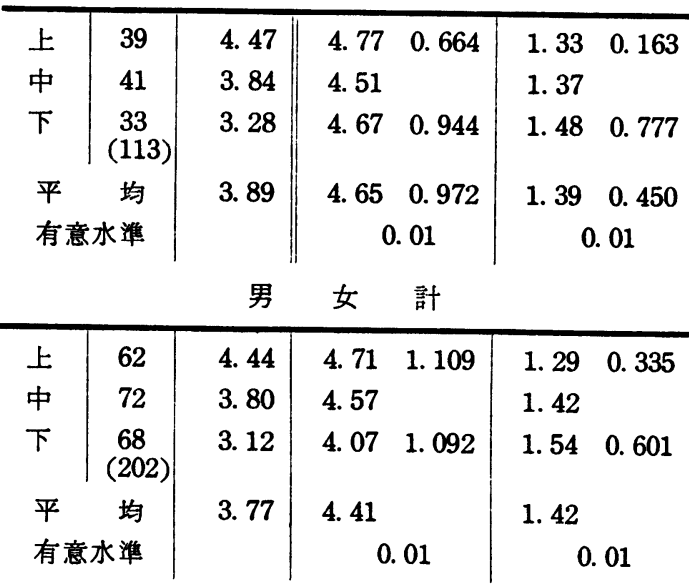

これをみると，優劣点で高い点をとつたものほど，そ らでないすのよりも自己嫌悪点においてょり高い成績を とり，偏見点においてより低い点数をとつていることが 明瞭に看取される。そしてこの場合には女子学生におい てもはつきり優劣点の高いものは低いものに比して偏見 点が低いことを示している。
以上の考察から次のことを一応いらことができるであ ろう。すなわち,

XP は自己嫌悪の傾向がいちじるしい，そして偏見的 な傾向は弱いという特徵をもつている。

(2) PP は自己嫌悪点や優劣点においてどのよ5な傾向 を示すか。

この目的で整理された結果が Table 8である。ここで

Table 8 男 子 学 生

\begin{tabular}{|c|c|c|c|c|c|}
\hline & 数 & 偏見点 & 眻悪点 SD $^{2}$ & 檪劣点 & $\mathrm{SD}^{2}$ \\
\hline 上 & 37 & 2.12 & 4. $30 \quad 1.450$ & 3. 46 & 1. 157 \\
\hline 下 & $\begin{array}{c}52 \\
(89)\end{array}$ & 1.00 & 4. $12 \quad 1.757$ & 3. 71 & 1. 375 \\
\hline 平 & 均 & 1.46 & 4. 20 & 3. 61 & \\
\hline \multicolumn{2}{|c|}{ 有意水準 } & & 0.01 & 0.01 & \\
\hline
\end{tabular}

女子 学 生

\begin{tabular}{|c|c|c|c|c|c|c|}
\hline 上 & 36 & 2. 22 & 4. 89 & 0.862 & 3. 80 & 0.792 \\
\hline 下 & $\begin{array}{l}77 \\
\text { (113) }\end{array}$ & 1.00 & 4. 56 & 0.998 & 3. 95 & 1.067 \\
\hline 平 & 均 & 1. 39 & 4. 65 & & 3. 89 & \\
\hline \multicolumn{2}{|c|}{ 有意水準 } & & 0.01 & & 0.01 & \\
\hline & & 男 & 女 & 計 & & \\
\hline 上 & 73 & 2. 16 & 4. 56 & 1. 233 & 3. 63 & 1.071 \\
\hline 下 & $\begin{array}{l}129 \\
(202)\end{array}$ & 1. 00 & 4. 38 & 1. 352 & 3. 85 & 1. 209 \\
\hline & & 1. 42 & 4. 41 & & 3. 77 & \\
\hline 有意 & 淮 & & 0.01 & & 0.01 & \\
\hline
\end{tabular}

上位群とは質問紙第 4 項の 2 以下に反応したグループで あり，下位群とは1に反応したグープである。本表か ら偏見点の高いものは低いものよりも，自己嫌悪点が高 く，優劣点において低い点数をとる傾向のあることが伺 い知られるであろう。したがつて,

PP も自己嫌悪の傾向が強い。しかし，外国びいきの 態度は弱いという特徵がある。

といらことができるょうである。それでは，自己嫌悪の 強弱によつて被験者を上中下 3 群に分類したら，上下両 群間にどのような差が認められるであろうか。

この角度から結果を整理しな扎してみると Table 9 のよ5になる。これをみると，自己嫌悪点の高いものは 低いものに比して，優劣点においても，偏見点において もより高い傾向をもつといらことがいえよう。この傾向 は男女のいずれの場合にも同様に現われている。

この事実は自己嫌悪の強いものには外国びいき的性格 の強いものと偏見的性格の強いものとが含まれているこ とを示しているといってよい。 
Table 9 男子 学 生

\begin{tabular}{|c|c|c|c|c|c|c|}
\hline & 数 & 息尊恚 & 優劣点 & $\mathrm{SD}^{2}$ & 偏見点 & $\mathrm{SD}^{2}$ \\
\hline 上 & 38 & 5.37 & 3. 82 & 1. 199 & 1.50 & 0.327 \\
\hline 中 & 40 & 3. 75 & 3.56 & & 1.45 & \\
\hline 下 & $\begin{array}{c}11 \\
(89)\end{array}$ & 1.73 & .3 .03 & 0.659 & 1.36 & 0.232 \\
\hline 平 & 均 & 4. 20 & 3. 61 & & 1.46 & \\
\hline \multicolumn{2}{|c|}{ 有意水敀 } & & 0.01 & & 0.01 & \\
\hline \multicolumn{7}{|c|}{ 女子学 生 } \\
\hline 上 & 65 & 5. 35 & 3.96 & 0.922 & 1.46 & 0.558 \\
\hline 中 & 44 & 3. 84 & 3. 80 & & 1.30 & \\
\hline 下 & $\begin{array}{c}4 \\
(113)\end{array}$ & 2.00 & 3. 75 & 0.956 & 1.25 & 0.187 \\
\hline 平 & 均 & 4. 65 & 3. 89 & & 1. 39 & \\
\hline \multicolumn{2}{|c|}{ 有意水準 } & & $0.02>p$ & $0>0.01$ & 0.01 & \\
\hline & & 男 & 女 & 計 & & \\
\hline 上 & 103 & 5. 36 & 3. 91 & 1.028 & 1.48 & 0.463 \\
\hline 中 & 84 & 3. 80 & 8. 68 & & 1. 37 & \\
\hline 下 & $\begin{array}{c}15 \\
(202)\end{array}$ & 1.80 & 3. 23 & 1.099 & 1.33 & 0.222 \\
\hline 平 & & 4. 41 & 3. 77 & & 1.42 & \\
\hline & & & 0.01 & & 0.01 & \\
\hline
\end{tabular}

ところで，Brodbeck と Perlmutter(11) とは自己嫌重 は Xenophilic Personality とも Authoritarian Personality とも関連をるつていることをあきらかにしこの 傾向が女子学生より男子学生においてよりいちじるしい と述べている。また Perlmutter(12)はこれら 2 つの Personalities はその民族的態度において論理的には両極的 でありながら，基本的には同一の人格性力学をるつてい ることを究明している。そして Authoritarian Personality そ Ethnocentric F'ersonality（自国民びいき的性 格の強いもの）と密接に関連していることはすでによく 知られてきているのであるから, 結局これら 3 つの Personalities は同根をるつた異なつた形の枝葉の奖に過ぎ ないすのであるといらことができる。

こ5見てくると，われわれの研究結果もこれを総合的 に考察してみると，外国びいき的性格と偏見的性格とは 本来同様の人格性力学をるつたるのであつて，自国民と 他国民とを強く差別する点では共通しているるのである といつてよい。それならば外国びいき的性格の強いるの はやはり偏見点が高いはずであるのに本研究では予想外 に低い結果となつているのはなせだろらか。Perlmutter は Xenophiles が権威に対して抱いている反感・不信・ 㪣意・攻撃を自己防衙過程によつて間接的投射的に解決 しようとするものであることをあきらかに論じているが
偏見点が期待に反して低いという事実すじつはかれらが 外国びいきの傾向や態度を隐蔽し，自国民を嫌つて他国 民を好むことに対する人間的罪悪感から逃れようとする 自己防衙過程としての逆反応を意味しているのではある まいか。この点について Perlmutter Xenophilesは 抽象的に人間性を受し，意識的に Humanitarians とな つていると考光るといつているが，偏見点の低い結果が 無意識的機制によるるのか意識的活動によるるのかにつ いてはさらに考究を要するところであると思5。

\section{V 要 粎}

われわれは民族的好悪とその人格性要因に関する問通 について男女 232名に対して行なつた調查結果を考察し てきたが，いまその主要な点を要䄪し列挙してみること としよう。

(1) 大学生の民族的好覀の状態は 5 年前の調査結果と比 聂して 0.874 とい5高い相関があり，かなりの一致性 がみられるが，特にシナ人・インド人・朝鮮人に対し ては一の方向に，オーストラリヤ人・スイス人・アメ リカ人に対しては十の方向にかなりいちじるしい変化 をきたしていた。

（2）民族的好悪感と民族的優劣観とは 0.760 の相関を示 し，相当の一致性のあることがわかつた。しかし，口 シア人・ユダヤ人・シナ人・アメリカ人においては好 悪感よりも優劣観においていちじるしく+であり，こ れに反し日本人・インド人・ビルマ人・フィリピン人 ・黒人に対してはいちじるしくーであることが注目さ れた。

（3）民族的好悪と人格性要因との関係については，

（i）外国びいきの性格の強もいのはそうでないもの よりす優劣点・自己嫌鱼点がより高く, 偏見点にお いてより低いといら傾向が顕著にみられた。しかし 偏見点が彼等においてより低いといらことは外国び いき自国ぎいとい5人間的罪悪感から逃れるため のかれらのとる自己防衙手段の現われではないかと 察せられる。

（ii）・偏見的性格の強いものはそうでないわのに比し て優劣点がより低く自己嫌悪点がより高いとい5傾 向が明瞭に看取された。

（iii） 自己嫌悪の強いものはそうでないるのよりも優 劣点も偏見点もより高いとい5傾向がはつきりうか がわれた。

（iv）したがつて，外国びいきの性格の強いものも偏 見的性格の強いものも基本的には同一の人格性力学

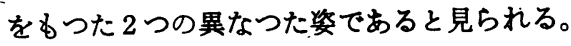


文

(1) Guilford, J. P. : Racial preferences of a thousand American university students. J. soc. Psychol, 1931, 2, 179-204.

(2) Hartley, E. L. : Problems in prejudice. New York; King's Crown Press, 1946.

(3) Seago, D. W. : Stereotypes : Before Pear Harbor and after. J. Psychol., 1947, 23, 55-63.

(4) Meenes, M. : A comparison of racial stereotypes of 1935 and 1942. J. soc. Psychol., 1943, 17, 327-336.

(5) Gilbert, G. M. : Stereotype persistence and change among college students. J. abnorm. soc. Psychol., 1951, 46, 245-254.

(6) Katz, D. \& Braly, K. W. : Racial prejudice and racial stereotypes. J. abnorm. soc. Psychol.,
$1935,30,175-193$.

(7) Ibid.

(8) Adorno, T. W. ; Frenkel-Brunswik, E. ; Levinson, D. J. \& Sanford, R. W.: The Authoritarian Personality. New York : Harper, 1949.

(9) Perlmutter, H. V. : Some characteristics of the xenophilic personality. J. Psychol., 1954, 38, 291-300.

(10) Brodbeck, A. J. \& Perlmutter, H. V. : Selfdislike as a determinant of marked ingroupoutgroup preferences. J. Psychol., 1954, 38, $271-280$.

(11) Ibid

(12) Ibid.

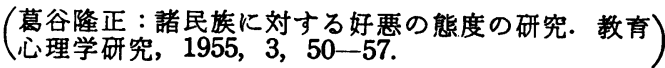
（1959年10月 5 日原稿受付） 


\title{
ABSTRACTS*
}

\section{STUDY ON STEREOTYPES AND PREFERENCES AMONG JAPANESE STUDENTS TOWARD THEMSELVES AND OTHER NATIONAL AND ETHNIC GROUPS}

\author{
by \\ Haratani, T.; Matsuyama, Y.; Minami, Y. \\ Osaka University of Liberal Arts and Education
}

The study of ethnic stereotypes is currently popular among the social psychologists. The present study has attempted to assess how Japanese students, in Osaka City verbalize images of themselves as a national group and images of eleven other foreign peoples who were expected to be valuable for a critical comparison. These eleven national and ethnic groups were American, British, Chinese, French, German, Indian, Italian, Jewish, Korean, Negro and Russian.

The entire procedure was modeled mainly after the procedure used by Katz and Braly. The first five traits selected out of 100 adjectives by the subjects consisting of three sampled groups (129 middle school students, 94 high school students and 70 college students) were given in order of percentage to indicate each stereotypy weight. Average index of stereotype consistency computed on each sample group was $.24, .28$ and .26 respectively.

The authors have considered about a relationship between stereotypes and prejudiced attitudes in terms of the ranking order assigned to these national and ethnic groups. The next two contrasting facts should be noted: A) Japanese students rank their own group at the top of preference ordering but reflect many unfavorable traits upon their self-attribution. B) Koreans are assigned to the bottom of preference ranking.

In summary, the following two comments have been drawn from this study: i) The lower indices of stereotype consistency found in these data might be understood that they reveal either differentiated or indifferent ethnic attitude in Japanese students. ii) Some inferiority-complex characterizing the selfattribution of these Japanese students might be projected in their Korean stereotypes.

\section{INTERRACIAL PREFERENCES AND THEIR PERSONALITY DETERMINANTS}

by

Kuzutani, Takamasa

Kumamoto University

This study aimed to compare the survey results on the interracial preferences of the university stu- dents who attended in 1954 with those in 1959, in order to explore the conformity of interracial pre-

* We owe editing of English abstracts in this issue to Dr. Ray Simpson of the University of Illinois. 
ferences to interracial evaluation of superiority or inferiority, and the relation between the interracial preferences and the personality determinants.

One hundred and six male and one hundred and twenty-six female students in the Faculty of Education of Kumamoto University were the respondents to the questionnaires made to indicate a degree of preference toward the twenty different races. To evaluate interracial preferences, subjects were asked to compare each race with the Japanese race on a 7 point scale. Then subjects were asked to rate their feelings of self-dislike on a 6 point scale and to select the most suitable opinion among five choices.

The results were as follows:

(1) There was a high correlation of 0.874 between the interracial preferences conceived by the university students investigated in 1954 and those in 1959. But considerable changes in preferences were revealed in a negative direction toward the Chinese, the Indians, and Koreans, and in a positive direction toward the Australians, the Swiss, and the Americans.

(2) The correlation coefficient of the interracial preferences with the interracial evaluation of superiority was 0.760 . The Russians, the Jews, the Chinese and the Americans, however, were rated remarkably higher in superiority evaluation than in preference; however, the Japanase, the Indians, the
Burmese, the Philippinoes and the Negroes showed higher preference than superiority evaluation. Thus, the interracial preferences and the interracial stereotypes have not always consistently appeared correlative.

(3) On the relation between the interracial preferences or the interracial evaluation of superiority and the personality determinants, the following tendencies have been found:

(a) Individuals who ranked Japanese at the 7th step in the scale or below in preferences have tended to score higher both on the racial evaluation scale and on the self-dislike scale, but lower on the racial prejudice scale, than those who did not.

This second tendency seems to be due to the results of the defensive processes by which they may escape from their guilty feelings regarding xenophilic attitudes as opposed to the domestic.

(b) Those who obtained higher scores on the prejudice scale were higher on the self-dislike scale and lower on the racial evaluation scale.

(c) Those who obtained higher scores on the selfdislike scale were higher both on the racial evaluation and on the prejudice scale. These results lead us to the-conclusion that there may be a certain similar underlying personality dynamics between the xenophilic $\cdot$ and the prejudiced.

\title{
FACTOR-ANALYTICAL STUDIES OF PICTURE-FRUSTRATION STUDY
}

\author{
by \\ Kuba, Tadatoshi \\ Yamaguchi University
}

The first aim of this investigation is to find out how the frustration of children changes annually in quality in the same child. The second aim is to find out the form of reaction or response and the direction of aggression by factor analysis. The Picture Frustration Study was administered to primary school children when they were in the $3 \mathrm{rd}, 4$ th, and 5 th grades.

Following are the results obtained:

(1) The form and direction of frustration changes from Extrapunitiveness to Intrapunitiveness or Impunitiveness as the age increases.

(2) The factor analysis results indicate Extrapunitiveness responses disappear as age increases. 